(c) The Author(s) 2021

p-ISSN: 2722-8894; e-ISSN: 2722-8886

DOI: $10.47043 /$ ijipth.v2i1.13

https://aafki-afti.org/ijipth

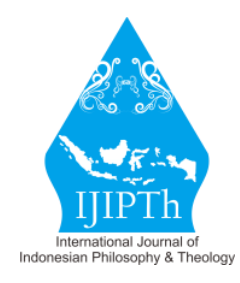

\title{
A Prophetic Pastoral of Presence: An "Exchange of Places." Re-contextualizing the Encounter of Jesus and the Leper in Mark 1:40-45 for the Role of the Asian Church in the Midst of Pandemic Covid-19
}

\author{
Gregorius Tri Wardoyo ${ }^{1}$, Yosafat Roni Sentosa ${ }^{2}$ \\ ${ }^{1}$ STFT Widya Sasana Malang, Indonesia \\ ${ }^{2}$ Universität Innsbruck, Austria \\ Email: gtricm@gmail.com, roniyosafat@gmail.com
}

\begin{abstract}
The pandemic of the Corona virus, known as Covid-19, has made the institution of the Asian Catholic Church somehow "stutter" in the spiritual services especially to the patients of the disease. In the light of Mark 1:40-45, we propose to the Asian Church to promote a prophetic presence, that is pastorally an "exchange of places" as done by Jesus Christ to the leper as a consequence of His action. To arrive at such a pastoral presence, we analyze the text of Mark 1:40-45 from the narrative perspective and inter-textual approach. We then invite the reader to see the basis and praxis of the "consciousness" of the Federation of Asian Bishops Conferences and how the Catholic Church is trying to show the loving face of God to the Asian people.
\end{abstract}

Keywords: the Asian Church, exchange of places, leper, pandemic covid-19, prophetic.

\begin{abstract}
Abstrak: Pandemi akibat covid-19 membuat Gereja Asia gagap dalam pelayanannya terutama kepada pasien covid-19. Dalam terang Markus 1:40-45, penulis mengusulkan kepada Gereja Asia untuk melakukan suatu pastoral kehadiran yang bersifat profetis, katakan saja "pertukaran tempat" seperti yang dilakukan oleh Yesus yang menggantikan posisi penderita kusta sebagai risiko tindakan-Nya. Untuk sampai pada kesimpulan tersebut, penulis mencoba untuk menganalisis teks Markus 1:40-45 dengan menggunakan metode naratif dan pendekatan intertekstual, kemudian pembaca diajak untuk meninjau kembali kesadaran FABC mengenai dasar dan praksisnya di Asia dan bagaimana Gereja Asia mencoba menghadirkan wajah Tuhan bagi orang-orang Asia.
\end{abstract}

Kata Kunci: Gereja Asia, pertukaran tempat, penderita kusta, pandemi covid-19, kenabian.

\section{Introduction}

One of the important keys to be reflected regarding the $50^{\text {th }}$ anniversary of the Federation of the Asian Bishop's Conferences (FABC) is "how can the Church in Asia continue to become the good news in light of the emerging realities?" One of the emerging realities as it is formulated in guide document of the FABC is the global pandemic due to covid-19 that emerged for the first time in Wuhan, China (about December 2019) and until now it still becomes a big problem in the world including in Asia. As a Church we seem to be slow in servicing the God people in the midst of this pandemic, especially for those who are suffering due to covid-19. The fear of infection by patients is one of the reasons for the slow of the priests in general. We hope that Jesus' actions as recorded in Mark 1: 40-45 can be used as a starting point for reflecting on the prophetic calling of the Asian Church. For this reason, this article shall proceed as following. First of all, this article will be dedicated to discuss the pericope of Mark 1:40-45, then we will see the messages of the pericope regarding to the context of the Asian Church. To grasp the messages of the studied texts, this study will employ some biblical approaches, like, a narrative 
criticism and intertextual approach. Finally, this article is intended as a small contribution for the FABC in their efforts to find a new model of pastoral in Asia, from the biblical perspective.

\section{The Narrative Analysis of Mark 1:40-45}

The narrative criticism puts the pericope of Mark 1:40-45 as one unit and constructs one story; it narrates a scene between Jesus and the leper and how Jesus has compassion toward him. The evangelist of Mark describes the gestures of the leper who came to Jesus: come to Jesus, plead to Jesus, to kneel down in front of Jesus. These gestures say that he is the humble person who recognises Jesus as one who has a divine power (cf. Mat. 9:8; Mark. 1:27).

The previous verse of Mark. 1:40-45, that is, Mark. 1:39 tells us that Jesus can drive out the demons. Probably, the leper already heard and knew who is Jesus. For this reason, he came to Jesus, pleaded him, and kneeled down saying, "If you are willing, you can make me clean!" It is interested here to pay attention to the verb that is used by the leper above. The leper uses the verb $\theta \dot{\varepsilon} \lambda \omega$ "to wish", "to want", "to desire" to express an exercising the will. This verb is often used of God (1Tim. 2:4), or of Christ (Mark 3:13). In responding him, Jesus also uses the same verb. At this point, Jesus shows us the importance of a good will in His service toward the leper. For the importance of this study, it is necessary to expound the reason for why the leper is marginalized by his/her fellow countryman.

In the Old Testament's culture, the leper is regarded as unclean person, and marginalized by the law (cf. Lev. 13). The law says, "And the leper in whom the plague is, his clothes shall be rent, and his head bare, and he shall put a covering upon his upper lip, and shall cry, unclean, unclean. All the days wherein the plague shall be in him he shall be defiled; he is unclean: he shall dwell alone; without the camp shall his habitation be" (Lev. 13:45-46). According to this law, we might imagine that the leper who came to Jesus was alone and was living outside of the camp. The good will of Jesus, however, does not prevent Him from receiving the leper.

In Mark 1:41 is told that Jesus even touched the leper. This gesture means that by His divine power Jesus blesses the leper which makes him cleanse (Harun, 2015). In the other places, people believe that by touching Jesus they will be saved or cured (Mark 6:56; Luke 8:47). Accordingly, the leper is cured from his leper and to be cleansed again.

The story does not end here. The ex-leper has to go to a priest and to make the offering as evidence that he is already cleansed (cf. Lev. 14). Instead of going to the priest, the man began to tell everyone what had happened to him. As a result, Jesus could no longer go openly into any town, but stayed outside in deserted places (Mark 1:45).

A critical reading on this pericope leads the potential reader to see that there is an exchange of places between Jesus and the leper (Poppi, 2012). The ex-leper freely goes to any town, anywhere he wants, and meets other people, whereas Jesus is not free to go to any town. Now, Jesus must stay outside in deserted places. The idea of an exchange of places could be seen in the large context of the life of Jesus. ${ }^{1}$

In the first place, we could relate this event to the incarnation of God in the form of human beings. The Apostle Paul articulated the humility of Jesus in his letter to the Philippians (2:5-11). Jesus emptied himself, taking the form of a slave, becoming as human beings are; and being in every way like a human

\footnotetext{
${ }^{1}$ Martin Harun sees that the difficulty of Jesus to enter freely to any town as the fault of the leper, whereas the author of this article sees it as a risk of a prophetic action of Jesus.
} 
being (Phil. 2:7). The act of Jesus to be human beings is contrary to the desire of the first human beings, that is, Adam and Eve who were willing to be like God (Gen. 3).

Furthermore, in the second place, the death of Jesus on the cross must be read as another action of Jesus as an exchange of places with human beings. Jesus died on the cross due to the sins of human beings, not his (1 Peter 2:24). For this, Jesus is raised up by His Father (Phil. 2:9).

To understand these actions of Jesus, the humility becomes an important key as it is highlighted by the Apostle Paul above. In the Paul's perspective, the humility is understood as giving "preference to others", instead of "self-interests" (Phil. 2:3-4). ${ }^{2}$

In light of Paul's letter to the Philippians, the action of Jesus in Mark 1:40-45 must be understood as His will to save others, in this case is the leper. Jesus does not think of himself; He prefers to save the others. Jesus sacrifices His freedom for the sake of the leper who is also a son of Abraham (Luke 19:9); he is served to be saved as well.

Finally, in light of Ezek. 37, the healing of the leper could be understood as a renewal of the covenant between God and His people. To grasp the message of the Prophet Ezekiel, the text of Ezek. 37 will be seen below:

"The Lord Yahweh says this: I shall take the Israelites from the nations where they have gone. I shall gather them together from everywhere and bring them home to their own soil. I shall make them into one nation in the country, on the mountains of Israel, and one king is to be king of them all; they will no longer form two nations, nor be two separate kingdoms. They will no longer defile themselves with their foul idols, their horrors and any of their crimes. I shall save them from the acts of infidelity which they have committed and shall cleanse them; they will be my people and I shall be their God." (Ezek. 37:21-23).

The purification of the leper, who is one of the Israelites, reminds the reader to the action of the God of Israel in restoring His people from the oppression of the foreign nations, namely from Babylon as it is reported by Ezekiel above. The liberation of the people of Israel should be seen as the effort of the God of Israel to maintain the sanctity of His people. In the Old Testament, the concept of holiness means that the God of Israel separated His people from the foreign nations; it means they are kept away from their gods. This idea is a part of the covenant between the God of Israel and His people which says "they will be my people and I shall be their God" (Desmond \& Baker, 2003). The God of Israel, who is faithful toward His promise, is always present among His people to save them.

The healing of the leper in Mark 1:40-45 by Jesus, therefore, is one of the good wills of the God of Israel in redeeming His people.

Hitherto, the text of Mark 1:40-45 is already analysed and we can conclude that for the salvation of the others, Jesus sacrificed Himself and freely accepted the risk of His service. In the following session, then, the prophetic action of Jesus will be expounded.

\section{The Act of Jesus as a Prophetic Expression}

The reflection on Mark 1:40-45 allows us to articulate the prophetic vocation of Jesus as a realization of His mission as noted in Luke 4:18-19, "The spirit of the Lord is on me, for he has anointed me to bring the good news to the afflicted. He has sent me to proclaim liberty to captives, sight to the blind, to let the oppressed go free, to proclaim a year of favour from the Lord" (Luke 4:18-19; cf. Mark 1). The

${ }^{2}$ In turn the Apostle Paul invited the Philippians to see him as a model in the humility as Jesus did. For a detailed study on Paul'kenosis see Dorothea Berthschmann, "Is There a Kenosis in This Text? Rereading the Philippians 3:2-11 in the Light of the Christ Hymn," in JBL 137/1 (2018), 235-254. 
mission of Jesus to "bring the good news to the afflicted" is deserved our attention and significant for our topic especially in relation to the question above, "how can the Church in Asia continue to become the good news in light of the emerging realities?"

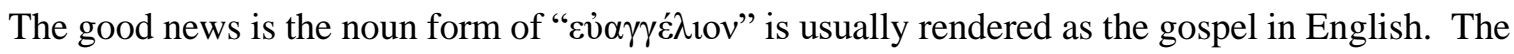
term of "gospel" itself is an abstract concept, as well as the term of the "good news." Therefore, it is necessary to grasp the meaning and the contents of the good news itself as follows (Wardoyo, 2021):

In the first place "the good news" might be understood that God, through His only Son, is always with us Immanuel (Matthew 1:23). That God is always with His people has been experienced by the Old Testament people, namely the nation of Israel, as the chosen people. God's participation in the lives of the Israelites was felt and experienced not only when they were in their own homeland, but also when they were in Egypt and in Babylon. This means, God never leaves His people. In the New Testament, God's promise to be with His people is evident in His Son who became man.

The second meaning of "the good news" is that God always offers opportunities for His people to repent and feel forgiven. The theme of repentance and forgiveness is not new in the New Testament. Since the first humans fell into the temptation of the serpent, God has continually offered and invited His people to repent. The invitation to repent on the part of God was done intensely by the prophets. The Old Testament can actually be read with a scheme of repentance and forgiveness. The Old Testament tells the journey of the people of Israel, their ups and downs in response to God's love. If we are careful in reading the Old Testament, we will see the dynamics of the people: sin-repent-forgiveness then sin-repent-forgiveness, and so on.

Departing from the above understanding, the action of Jesus in Mark 1:40-45 is an evidence of the presence of God among His people. The presence of God, therefore, is the good news for the leper. He does not feel alone; there is God with him. Through Jesus, he could experience the presence of God who saved him from his sins by curing him from the skin disease. Jesus brings the compassionate God's face. The face of God that is seen in the figure of Jesus is contrast to the Old Testament's God which is described in various faces. God of the Old Testament is usually depicted as jealous, angry, and as a warlord.

Despite such images of God in the Old Testament, it is necessary to underline that God of Israel which is told in their book is one who is present in the history of His people. That God lives among us should become our awareness. The Israelites realize the presence of God, especially through their experience in the Exodus's event. They understood the Exodus from Egypt as the intervene of their God. This experience becomes their basis to see that they are a chosen nation. God by liberating the Israelites from slavery in Egypt has separated them from the Gentiles and now they are obliged to worship the God of Israel as the only God in this world.

The God of Israel, thus, is one who lives in the history of His people and until now He still works in this world (cf. John 5:17). For this, Jesus is working as well. This understanding of God is highlighted in the Book of the Prophet. For this, the image of God in the Book of Ezekiel will be presented here.

The study on Ezek. 21:1-32 and the restoration of Israel in Ezek. 37:15-28, 39:23-29, and selected passages from 40:1-48:35 suggests that the image of the God of Ezekiel could be defined by His actions. In the other books of the HB, the image of God is commonly described with the adjectives "compassionate and gracious" (See Neh 9:19; Ps 78:38). For instance, Exod. 34:6 depicts God as one who is compassionate and gracious, slow to anger, and abounding in lovingkindness and truth (see also Deut 4:31; 2 Chron 30:9; Neh 9:17, 31; Pss 78:38, 86:15, 103:8, 111:4, 145:8; Joel 2:13; Jon 4:2.). 
In the Book of Ezekiel, the adjectives "compassionate and gracious" to describe the image of God are absent. In the place of such adjectives, the Book of Ezekiel has the verb "to have mercy" (cf. Ezek. 39:25); this supports the opinion that Ezekiel's God may be defined and known by His activities in the world, particularly in the midst of His people (Nielsen, 1978). Commonly in the HB, the authors do not speak of "God per se but of what God says, how [H]e acts and how $[\mathrm{H}] \mathrm{e}$ is experienced" (Rendtorff, 2005; Kaiser, 1998). In what follows, we will present some examples of the actions of God both violent and merciful, outside of Ezek. 21:1-32, 37:15-28, 39:23-29, and 40:1-48:35.

The violent acts of God in the Book of Ezekiel are described as follows: God punishes His people in a triad of afflictions, namely, plague, famine, and sword; they or some of them also will be applied to punish the nations (e.g., Ezek. 5:12, 6:11, 28:23, 36:29-30). In addition, in Ezek. 6:10, God underlines that He Himself would afflict His idolatrous people (Tooman, 2009). In the same chapter, God will stretch out His hand against His people and their land (Ezek. 6:14).

Divine retribution extends not only toward Israel, but also against her foes. The oracles against the nations are narrated in Ezek. 25-32, 35, and 38-39. They are enemies of His people, so God will defend His people by punishing Israel's foes (Savoca, 1976: 146). ${ }^{3}$ To Edom and Egypt, God proclaims that He will stretch out His hand against them, cutting down man and beast from among them (Edom and Egypt) (Ezek. 25:13, 29:8). God also will execute great vengeance upon Philistia with furious rebukes (Ezek. 25:17). In the oracle against Sidon, God will send to (Sidon) plague and blood in her streets, as well as draw the sword upon her on every side (Ezek. 28:23). Against Egypt God will set a fire and destroy her helpers (Ezek. 30:8); He also will destroy the Egyptian gods and their temples (Ezek. 30:15-19) (Smith, 1931). Finally, Ezek. 39:6 narrates that God will send a fire against Magog. By defeating Magog, the people of Israel do not need to defend themselves; as a consequence, they will burn their armies (Ezek. 39:9).

In other passages, God shows His mercy toward His people through His acts as well. In the context of the oracle of judgment, Ezek. 12:16 depicts the mercy of God when God will spare a few of His people from the sword, the famine, and the plague so that they will admit their sin in Babylon among the other nations (Lind, 1996). Furthermore, the mercy toward His people is shown by His future blessing as it is found in Ezek. 28:25: "[w]hen I gather the house of Israel from the peoples among whom they are scattered and shall manifest my holiness in them in the sight of the nations, then they will live in their land which I gave to my servant Jacob." As a result of God's blessing, the people will live in a peaceful land. Finally, God Himself will be the Shepherd of His people, as it is narrated in Ezek. 34. As the Shepherd, God is present in the midst of His people and will re-gather and rule over them (Ezek. 34:30).

The passages cited above, then, confirm that the God of Ezekiel is a living God who acts in history (Wénin, 2008). Donald E. Gowan's statement supports this conclusion: "[t] $]$ he God revealed in Ezekiel is one who acts with terrifying and unrelenting anger against a sinful people [...]. The God revealed in Ezekiel is also one who longs to forgive and who has the power to do so" (Gowan, 1998). The God of Ezekiel, therefore, is the God who acts both violently (e.g., Ezek. 7:19, 8:18) and mercifully in the history of His people (e.g., Ezek. 6:8, 39:25).

${ }^{3}$ For further study on God's judgment upon the nations See Paul R. Raabe, "Transforming the International Status Quo. Ezekiel's Oracles against the Nations”, in William A. Tooman-Michael A. Lyons (eds.), Transforming Visions. Transformation of Text, Tradition, and Theology in Ezekiel, Pickwick Publications, Eugene 2010, 187-207. 
In sum, in the Scripture both in the New Testament and in the Old Testament, God is depicted as One who is present in the history of His people and He is working until now as it is depicted in the figure of Jesus who was present among His suffered people.

The good news or the gospel, therefore, is not an abstract concept; it is real in the presence of Jesus. Jesus shows us His compassion toward the afflicted. This is His prophetic mission in this world as it is proclaimed by the Evangelist Luke. The question is how does the Asian Church try to follow Jesus as our model to serve the Asian people particularly in the midst of pandemic covid-19?

\section{The Prophetic Vocation of the Asian Church}

The question, "how does the Asian church try to follow Jesus as our model to serve the Asian people particularly in the midst of pandemic covid-19?" allows us to review the consciousness of the FABC since its foundation, fifty years ago.

Firstly, the FABC has based their theological-pastoral axis on the "triple dialogue", that is, dialogue with the poor, with cultures and with religions. This means that dialogue is considered as the best way for the Asian Church to be present among the Asian people, especially the poor, one who has different backgrounds of culture, and religions.

Second, the FABC is meant first of all to create a collaboration among the bishops of Asia. The goal of the FABC is to build the sense of collegiality, communion, solidarity, and synodality in the Asian Church. Therefore, this aim is internal so that the bishops might participate in the ongoing formation for the ministry in Asia in order that the missionaries could bring the love of God among the people of God in Asia.

The third consciousness of the FABC still focus on the formative aspect, namely to provide and facilitate various resources like programs, initiatives, and collaborative efforts. The target of this program is seminaries and other formation institutions in the hope that this will inspire deeper reflections for more creative pastoral applications since "we need a church capable of walking at people's side, of doing more than simply listening to them; a church that accompanies them on their journey" (Pope Francis, World Youth Day, Rio de Janeiro 2013).

In the fourth place, the FABC is aware of the fast developing in the field of communication in this era of information and technology. The FABC considers these changes as a positive thing to increase collaboration among their member. Furthermore, in the midst of pandemic covid-19, the FABC sees the digital era characterized by the internet of thing as an opportunity to serve the people of God and to build the solidarity among the churches in Asia both sacramental and non-sacramental aspects, although via online.

Fifthly, as an organization, the FABC has already equipped itself with the good structure to be able to serve the various needs of the people in Asia. This is a vivid evidence that the Asian Church is always trying to be present by responding the needs of the churches in Asia.

The FABC realizes its vocation not only to serve the Asian people but also to serve the world. For this, the number six of their consciousness points out the importance of the need to enter into partnerships for the promotion of the common good of all. This consciousness actually is not new for the FABC as it is noted in number seven which reports the sacrifices and the generosity of the Asian Churches toward other churches in the world. This good will of the FABC aims to participate and promote the mission and dialogue for the sake of the work of God. 
Lastly, the FABC recognizes the sacrifices of the past missionaries who have constructed and brought the Christian faith in the land of Asia. To thank to them for their services, the Asian Church continually sends the missionaries to other places throughout the world as well to proclaim the good news that is Jesus Christ.

Having reviewed the concerns of the FABC from the beginning of its foundation till nowadays, then it is necessary to reflect the possibilities for the FABC in responding the emerging realities due to the pandemic covid-19 through new pathways, in particular by drawing the inspiration from the Scripture as the main source in theology.

The reflection on Mark 1:40-45 above could be a starting point for the FABC to follow the footsteps of Jesus. Jesus shows us the way to present the face of God who has compassion toward the afflicted and the marginalized person. To do so, Jesus must take a big risk by sacrificing Himself. The FABC itself already carried out the "pastoral of presence" among the Asian peoples. However, a particular response to those who are suffered due to covid-19 is still absent from their consciousness cited above.

Let us remember those who are affected by covid-19. They must be isolated from other people to prevent transmission of the coronavirus disease. As soon as they go to the hospital, there are two possibilities, go home to see their family again, or they do not meet their beloved more because of their death. In other words, they have to go through their life alone without accompanying their beloved one. This is a new poverty as it is seen by Mother Theresa toward those who are dying unaccompanied. This reality urged her to serve the dying poor in Kolkata, India in the hope that they feel be loved in the end of their life.

Those who are isolated because of covid-19 are not different from those who have leper who dwell outside their village. This difficult situation makes the church in the world as well as in Asia stuttering, especially in the sacramental services for those who are dying. Our traditional services as it is practised currently by the church faces a big question on how could the church carry out their sacramental services for them, like the sacrament of reconciliation and for the sicks. For the reason of adhering to health protocols, many dying people due to covid-19 cannot receive services from the church. How pity they are!

The FABC is challenged to find a new way to serve them. It would be good if here we take some examples of the heroism of a few people in helping those who are sick because of Covid.

There is a viral video on social media which tells the heroic story of a farmer in a village in India who is willing to sacrifice himself to save his neighbours, especially from Covid. he turned his motorbike into an ambulance to get the sick to the clinic. In the end he himself set up a medical centre in his village. Does this action make the church even more courageous in giving itself for the salvation of many people?

The other example comes from Venezuela in South America. It is reported that there was a priest who died due to covid-19. This priest was a chaplain in one of the hospitals in Venezuela. The witnesses who live with him said that that priest was very generous in servicing the sick people including those who are suffered from covid-19. As a consequence of his generosity, he must sacrifice his own life for the sake of the mission of the church.

These heroic examples should open the eyes of the Asian Church. The examples and the blood of saints and martyrs who sacrificed their life for Asian people and in Asia should encourage the Asian church, in particularly the missionaries, to sacrifice their life as well. The sayings of Jesus that "anyone 
who finds his life will lose it; anyone who loses his life for my sake will find it" (Matt. 10:39) is good to be reflected by the Asian church.

In light of Mark 1:40-45, the FABC might participate in the mystery of the incarnation of Jesus. The exchange of places between Jesus and the leper is the expression of His other incarnation in term that Jesus took place the human beings who suffered, in this case from the leper. Therefore, the Asian church has a duty to multiplicate the incarnation of Jesus, that is, to dare to take risks from serving other people, especially those who are suffered from covid-19. In the history of church, there are many saints who are affected by the pandemic because of pest, and other plague and they had to lose their life for the sake of salvation. In other words, the service of the church is not absent of the sacrifice as an offering to God. The "pastoral of presence" as the FABC is initiated might be understood in the frame of exchange of places as Jesus did in His life.

This interchange supposes an interpersonal encounter. The good example of interpersonal encounter could be found in the scene of the visit of Mary to Elisabeth when they conceived of Jesus and John (Luke 1:40-45). The visit of Mary to Elisabeth brings a joy as it is described by the Evangelist Luke very well. The same joy is also experienced by the leper who met Jesus. He expresses his joy by telling to everyone that he is now cleanse and free from leper.

\section{Conclusion}

Jesus Christ, in the gospel of Mark 1:40-45, shows the real face of God who is compassionate toward one who is abandoned and marginalized by his fellow countryman. His action might open the eyes of the Asian church in relation to the question "how can the Church in Asia continue to become the good news in light of the emerging realities?" Moreover, the encounter between Jesus and the leper also opens our eyes that God does not condemn His people as well as the covid-19 is not the punishment of God toward His people. The pandemic due to covid-19 might be understood as a way of God to reveal His love toward human beings, and as a vocation of the Asian Church to be present among the suffered people due to covid-19 as well.

Finally, the concrete action of Jesus points out the true meaning of the pastoral of presence, that is, there must be a personal encounter with those who suffer from the coronavirus disease as one of the emerging realities in Asia. As a consequence of following the footsteps of Jesus is the Asian Church must have the courage to meet the victims of covid-19, even at the risk of contracting them; they are "too a son of Abraham" (Luke 19:9). Such a pastoral of presence might be considered as a true and concrete calling of the Asian Church nowadays in the midst of pandemic of covid-19. This pastoral of presence will be the real good news which might be applied by the Asian Church in the context of Asia.

\section{References}

Desmond, A. T. \& Baker, D. W. (2003). Dictionary of The Old Testament: Pentateuch. Downers Grove: InterVarsity Press.

Berthschmann, D. (2018). Is There a Kenosis in This Text? Rereading the Philippians 3:2-11 in the Light of the Christ Hymn. Journal of Biblical Literature, 137(1), 235-254.

FABC 50 General Conference, Guide Document, FABC 50: Journeying together as peoples of Asia “...and they went a different way.” (Mt 2:12).

Gowan, D. E. (1998). Theology of the Prophetic Books: The Death \& Resurrection of Israel. Louisville: Westminster John Knox.. 
Harun, M. (2015). Markus: Injil yang belum selesai. Yogyakarta: Kanisius.

Kaiser, O. (1998). Der Gott des Alten Testaments: Wesen und Wirken. Theologie des Alten Testaments Teil 2 Jahwe, der Gott Israels, Schöpfer der Welt und des Menschen. Göttingen: Vandenhoeck \& Ruprecht.

Lind, M. C. (1996). Ezekiel. Scottsdale: Herald Press.

Nielsen, K. (1978). Yahweh as Prosecutor and Judge. JSOT, Sheffield.

Poppi, A. (2012). Sinossi e commento: Esegetico-spirituale dei quattro vangeli. Padova: Messaggero.

Rendtorff, R. (2005). The Canonical Hebrew Bible: A Theology of the Old Testament. Leiden: Deo Publishing.

Savoca, G. (1976). Un profeta interroga la storia. Ezechiele e la teologia della storia. Roma: Herder.

Smith, J. (1931). The Book of the Prophet Ezekiel: A New Interpretation. London: Macmillan Co.

Tirimanna, V. (2020). Fifty Years of Asian Pastoral Guidance: Collections of the Statements of Asian Bishops' Meeting and the Plenary Assemblies of the Federation Asian Bishops' Conferences (FABC) (1970-2020). Yannawa-Bangkok: Hemmarus Prepress.

Tooman, W. A. (2009). Ezekiel's Radical Challenge to Inviolability. ZAW, 121, 498-514.

Wardoyo, G. T. (2021). Amanah Agung Tuhan Yesus dalam Keempat Injil, dan Implikasinya dalam Memahami Injil, Budaya, dan Pewarta Injil. Logos, 18, 31-47.

Wenin, A. (2008). La Bible ou la violence surmontée. Paris: Desclée de Brouwer. 